\title{
MEASURING EMPLOYEE PERFORMANCE WITH THE HUMAN RESOURCE SCORECARD APPROACH PT MATAHARI DEPARTMENT STORE CIPUTRA CIBUBUR
}

\author{
*Nuraeni ${ }^{1}$, Muhammad Sidik ${ }^{2}$, Rifzaldi Nasri ${ }^{3}$, M. Yusuf ${ }^{4}$ \\ 1,2,3,4 University of Muhammadiyah Jakarta \\ *Coresponding author. \\ E-mail addresses: nur.aini@umj.ac.id
}

\begin{abstract}
ARTICLE INFO
Article history:

Received:

21 August 2021

Accepted:

15 October 2021

Available online: 26 November 2021

ABSTRACT

This study aims to identify and develop employee performance measurement using the Human Resources Scorecard approach. This performance measurement is to determine the level of success of the Human Resources Division's strategy which has been measured using the Key Performance Indicator / Performance Appraisal by PT Matahari Department Store Ciputra Cibubur. The research method used is qualitative and quantitative analysis. In this study, a strategic map for the Human Resources division was designed and the success indicators of each strategic objective and performance measurement of human resources were identified using the "Human Resource Scorecards" method based on the Cal Hierarchy Process (CHP) analysis tool. The results of this study recommend a strategy map and human resource assessment card for each objective strategy to the Human Resources division at PT Matahari Department Store Ciputra Cibubur, so that performance assessment can be easier.
\end{abstract}

Keyword: Human Resource Scorecard, Key Performance Indicator, and employee performance appraisal.

\section{INTRODUCTION}

The development of the current era of globalization is so fast that it makes competition in the business world increase. Therefore, every company must strive to make efficiency and effectiveness of the company's performance so that it can face competition. Becker, Huselid, and Ulrich (2009, p. 112) "Saying the achievement of corporate strategic goals can be identified by measuring the overall performance of the performance indicators for each strategic goal".

Performance is a very important and interesting part because of its proven benefits, efforts to improve employee performance are the most serious management challenges because success in achieving goals and company survival depends on the quality of performance of human resources in it, therefore the need for measurement. employee performance.

Wibowo (2009, p. 67) "Mentioning the measurement of performance needs to be done to find out whether during the implementation of the performance there is a deviation from the predetermined plan, or whether the performance can be carried out according to the specified schedule, or whether the performance results have been achieved as expected. ".

Many factors influence business improvement, not only in terms of customer, product, demographic and other factors but also from human resource factors. The increasing demands for the quality of human resources 
have resulted in increased competition in the business world, thus encouraging companies to make improvements in measuring ongoing business performance. The results of this measurement help management to make efforts to improve processes and overall organizational performance.

Traditional performance measurement that is oriented to a financial point of view cannot measure all the capabilities of the company, because it requires a measurement system approach that can accommodate all the potential that the company has. Each company is required to be able to carry out its strategy in facing competition and use human resources more effectively and efficiently, which ultimately means that the company's vision, mission, and strategy can be implemented and run as expected. Hans (2014) "Suggests that human resources (Human Resource) are one of the major factors for the development of a company's business. Human Resources are also the company's greatest asset, so it can be said that behind a successful company there are excellent Human Resources".

Rivai and Mulyadi (2011, p. 324) "Suggest that in assessing the performance of an employee, various aspects of assessment are needed, including knowledge about work, initiative leadership, quality of work, cooperation, decision making, creativity, reliable planning, communication, intelligence ( intelligence) problem solving, delegation, attitude, effort, motivation, and organization ".

Balanced Scorecards complement a set of financial measures of past performance with measures of the drivers of future performance. The goals and measures of the scorecard are derived from the vision and strategy. Goals and measures view the company's performance from four perspectives. These four perspectives provide the framework for Kaplan and Norton's (1996: p. 8) Balanced Scorecard.

Table 1. Performance Appraisal PT. Matahari Department Store 2019 PERFORMANCE APPRAISAL (PA RATING FORM) 2019

(Assessment Indicator)

PA Period:
\begin{tabular}{|l|l|}
\hline NAME & Full Year \\
\hline POSITION & : MDS Ciputra Cibubur \\
\hline DIVISION & : Store Manager \\
\hline DEPARTMENT & : SO \\
\hline
\end{tabular}

\begin{tabular}{|l|l|}
\cline { 2 - 2 } \multicolumn{1}{l|}{ Time: } & 01-Jan to 31-Dec \\
\hline GRADE $\quad:$ \\
\hline NIK. $\quad:$ \\
\hline \\
\hline BARC. PRO : \\
\hline TMK. $\quad:$ \\
\hline
\end{tabular}

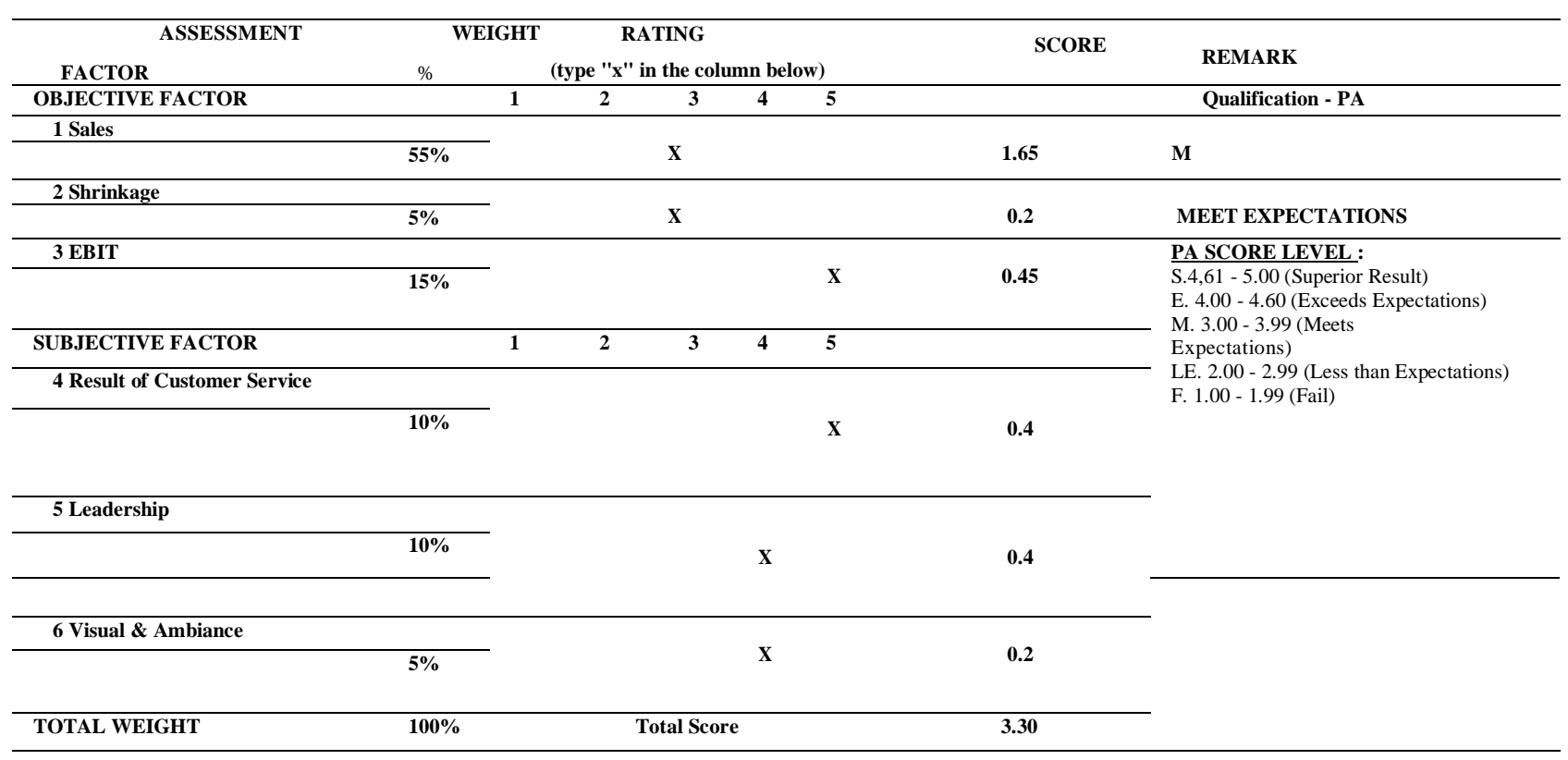




\begin{tabular}{cccc}
\hline Incumbent & 1st Assessor & 2nd Assessor & HRD-Division \\
\hline & & \\
\hline
\end{tabular}

Source: Matahari Department Store, Ciputra Cibubur

From the table above, it can be concluded that the assessment of HR performance at PT Matahari Department Store is still at a less than good level. Problems in PT. Matahari Department Store Ciputra Cibubur has not conducted performance measurements using the Human Resource Scorecard, while on the other hand, this measurement will better understand employee performance more closely and better understand what the company lacks and what will be the next improvements. Based on current conditions, therefore, it is necessary to improve employee performance measurement using the Human Resource Scorecard method. In the concept of the Human Resource Scorecard itself, companies can process responsibilities and strategies effectively to face future competition. This company was chosen because there has never been a measurement of employee performance in improving human resources.

Rusindiyanto (2009) suggests that through the Human Resource Scorecard method, the key characteristics of the company can be identified and evaluated so that improvements can be made which can bring positive changes to the company so that the company can determine the right steps to improve the performance of its employees. Masruroh (2008) in his research suggests that the Human Resource Scorecard is a human resource performance measurement system that links people, strategies, and performance to produce a superior company. From previous research, it can be seen that some of the advantages and benefits of the company if implementing the Human Resource Scorecard correctly and properly, the Human Resource Scorecard can describe the role and contribution of human resources to achieving the company's vision and mission clearly and measurably, providing a clear picture of the cause and effect relationship between departments, and professionally maximize human resources and manage their responsibilities.

Research conducted by (Zaini \& Suryadi, 2020)concluded that from the four existing perspectives, the perspective of internal business processes produces the best score, while the financial and learn and growth perspective produces moderate scores, and the weakest is the customer perspective. While(Industry, 2017) in his research at PT Rajawali Tanjungsari concluded that the measurement of performance using HRS with four indicators had an increase in HR performance from 2005 to 2006.

(Sahaya \& Wahyuni, 2017) In his research at PT Bella Citra Mandiri, it was concluded that the perspective of Customers and Consumers was the best with moderate issues. The same results also occurred in research. (Welan et al., 2018)(Ariningsih, 2014). With this performance measurement, it is hoped that it can help PT. Matahari Department Store Ciputra Cibubur to make improvements and increase the overall performance of its employees. Therefore, this research was conducted to measure the performance of human resources in PT. Matahari Department Store Ciputra Cibubur and if later there is a performance of human resources that is not yet optimal, it is hoped that improvements will be able to improve the performance of human resources and be able to maximize company profits and be able to compete with other companies.

Researchers used a qualitative descriptive research method, with the Analytical Hierarchy Process (AHP) method. A method developed by Thomas L. Saaty. AHP is a general theory of measurement used in determining the ratio scale. AHP has a basic input in the form of a ratio scale. The model used a limit of 1 to 9 which is considered to represent the perception of humans.

Table 2. Perception Scale 


\begin{tabular}{cll}
\hline Level of Importance & \multicolumn{1}{c}{ Definition } & \multicolumn{1}{c}{ Information } \\
\hline 1 & Equal Importance & $\begin{array}{l}\text { In both elements have the same effect } \\
\text { important }\end{array}$ \\
\hline 5 & More important & $\begin{array}{l}\text { Assessment and Experience are very } \\
\text { partial to one element compared to the } \\
\text { element of their partner }\end{array}$ \\
\hline 7 & $\begin{array}{l}\text { One element is very much liked and } \\
\text { practically its dominance is very real, } \\
\text { compared to the element of its partner }\end{array}$ \\
\hline 9 & Very important & $\begin{array}{l}\text { An element proved to be very } \\
\text { favorable }\end{array}$ \\
\hline $2,4,6,8$ & Absolutes are more & $\begin{array}{l}\text { One element proves to be preferable to } \\
\text { its counterpart in the highest belief }\end{array}$ \\
\hline & Middle value & $\begin{array}{l}\text { Awarded when there is a doubtful } \\
\text { judgment between two adjacent levels } \\
\text { of importance }\end{array}$ \\
\hline
\end{tabular}

Source: Thomas L Saaty

\section{LITERATURE REVIEW}

Ya Fen Tseng and Tzai Zang Lee (2006) in their research involved 129 companies in the Taiwanese electronics industry and 112 branches in China with the proposed AHP/DEA model. This study contains five variables of human resource practice and seven variables of organizational performance through Linear Structure Relations (LISREL). The main findings suggest: (1) asking employees to participate in company activities, as doing so can be very consuming on employee relations in any type of organization for both the Taiwanese electronics industry and branches; and (2) the importance of employee relations is more significant in the strata and rational culture than in the general development and culture regardless of the Taiwanese company or branch in China.

Fatih Tüysüz and Cengiz Kahraman (2006) on their research "Project Risk Evaluation Using a Fuzzy Analytic Hierarchy Process: An Application to Information Technology Projects said The fuzzy analytic hierarchy process $\sim$ AHP! as a suitable and practical way of evaluating project risks based on the heuristic knowledge of experts is used to evaluate the riskiness of an information technology IT! project of a Turkish firm. The means of the triangular fuzzy numbers produced by the IT experts for each comparison are successfully used in the pairwise comparison matrices

K. Hafeez (2007) in his research said their analysis illustrates that the intellectual assets such as marketing knowledge, design skills, manufacturing skills and customer relationship those usually ignored within the balance sheet of a company have been perceived relatively important than the tangible assets such as space and equipment.

\section{METHODS}

This study uses a qualitative descriptive research method that allows a researcher to interpret and explain a phenomenon holistically using words, without having to rely on a number. Djaman Satori (2011, p. 23) "Reveals that qualitative research is conducted because researchers want to explore unquantifiable phenomena that are descriptive. Thus, researchers used a qualitative descriptive research method, with the Analytical Hierarchy Process (AHP) method. This study explores the performance of employees at PT. Matahari Department Store Ciputra Cibubur.

Sources of data used are primary data sources, secondary data. Primary data is data that is created by a researcher for the specific purpose of solving the problem he is working on. The data is collected by the researcher directly from the first source or the place where the object of research is carried out using a questionnaire while secondary data is data that has been collected for purposes other than solving the problem at hand. This data can be found quickly. Informants, namely people in the research background who are used to provide information about the situation and conditions of the research background. Informants are important objects in a study, therefore we need informants. In this study, the secondary data sources are literature, articles,

Data collection techniques are very important in research because the purpose of the research is to collect data, this study uses qualitative techniques, namely, 1) Observation, 2) Interview, and 3) Documentation.

Steps research that done is described below:

1. Identification Stage 
This stage begins by identifying and formulating the problem, where the problem in this study is knowing the existing conditions of measuring the performance of human resources based on the Human Resource Scorecard approach. Furthermore, it is continued with literature study and field studies.

2. Design Stage

At this design stage, a human resource system design is carried out using the Human Resource Scorecard approach.

a. Defining business strategy clearly This definition is done by translating the company's vision, mission, strategy, and policies into strategic objectives for each perspective.

b. Building a business case for Human Resort where Human Resources are the company's strategic assets. The business case for Human Resources is how Human Resources can maintain the company in optimizing employee performance in meeting employee satisfaction.

c. Creating a company strategy map The strategy map is a graphical representation of the company's value chains. That is, it is a representation describe How Human Resources and line managers work together in creating value (value) within the company and also accommodate the roles of para employees in creating that value.

d. Defining Human Resource Deliverable in a strategy map. Furthermore, the fourth step is to define Human Resource Deliverable in a strategy map, namely at the point where it can contribute to implementing the company's business strategy. Human Resource Deliverable contained in perspective and strategic maps with benchmarks.

e. Aligning Human Resource Architecture and Human Resource Deliverable. The process that needs to be done at this step is to understand what is needed and what is necessary done to shows how the form of good alignment between the Human Resource system and the implementation of the strategy to produce Human Resource Deliverable.

f. Designing the system measurement strategic source power human. After defining the interrelationships between Human Resource Architecture with Human Resource deliverables The next step in designing the Human Resource Scorecard is designing a strategic human resource measurement system.

3. Measurement Stage

The measurement stage begins with weighting, where the weighting together of actual and target data is used to try out the performance measurement, namely determining the score for the achievement of the human resource system performance.

a. Weighting is done using the Analytical Hierarchy Process (AHP) method, to determine the weight of the level of importance of each strategic objective perspective. The weighting results are used to calculate the achievement score for human resource performance.

b. The total human resource performance of the weight multiplied by the score of each strategic objective in strategic objectives, resulting in a score for achieving the performance of strategic objectives. The total weight multiplied by the score of each strategic objective in its perspective results in a score for achieving that perspective. Likewise, the total weight multiplied by the performance achievement score for each perspective, resulting in an overall human resource performance score

The stages in data processing are as follows:

1) The initial stage starts with problem identification, at this stage the identification of problems that exist in the company is carried out.

2) The second stage is the identification of KPIs for the Human Resource Scorecard method where KPIs are obtained from 4 perspectives in this method. At this time, the supervisor or competent person has an important role in making decisions in determining KPI in every perspective.

3) The data begins with the observation stage to interview with HR Supervisor and Ast store manager at PT Matahari Department Store Ciputra Cibubur. Then look for the data information needed and then the data is processed with the help of Microsoft Excel.

4) In weighing the method used is AHP (Analytical Hierarchy Process) where this method is used to determine the priority of the level of importance.

\section{FINDINGS AND DISCUSSION}

Results of Variable Analysis of the HRSC assessment components

Table 3. Performance Appraisal Criteria 


\begin{tabular}{|c|c|}
\hline Performance Indicators & Assessment \\
\hline $4-5$ & Superior Result \\
\hline $3-3.99$ & Meets Expectations \\
\hline $1-2.99$ & Fail \\
\hline
\end{tabular}

Table 4. Measurement of the Human Resources Scorecard Design of PT Matahari Department Store Ciputra Cibubur

\begin{tabular}{|c|c|c|c|c|c|c|c|c|c|c|}
\hline Perspective & $\begin{array}{c}\text { Strategic } \\
\text { Objectives }\end{array}$ & $\begin{array}{l}\text { Weight } \\
\text { Priority } \\
\text { as }\end{array}$ & $\begin{array}{c}\text { Result } \\
\text { Measure }\end{array}$ & Score & Target 2019 & Actual 2019 & $\begin{array}{c}\% \\
\text { Achievement } \\
\text { Target }\end{array}$ & $\begin{array}{c}\text { Indicator } \\
\text { Performa } \\
\text { nce }\end{array}$ & $\begin{array}{c}\text { Score } \\
\text { Heavy } \\
\text { weight }\end{array}$ & Assessment \\
\hline \multirow{5}{*}{ Finance } & \multirow[t]{4}{*}{$\begin{array}{l}\text { Sales } \\
\text { Increase }\end{array}$} & 0.73 & $\begin{array}{l}\text { Annual sales } \\
\text { percentage }\end{array}$ & 3 & $\begin{array}{l}\text { Rp. } \\
104,866,556,980\end{array}$ & $\begin{array}{l}\text { Rp. } \\
104,997,260,386\end{array}$ & $100.12 \%$ & & 2.19 & \\
\hline & & 0.20 & $\begin{array}{l}\text { Percentage } \\
\text { of Operating } \\
\text { Profit }\end{array}$ & 5 & $\begin{array}{l}\text { Rp. } \\
20,737,000,000\end{array}$ & $\begin{array}{l}\text { Rp. } \\
11,639,000,000\end{array}$ & $178.17 \%$ & & 1.00 & \\
\hline & & & Shrinkage Loss & & Rp. & Rp. $336,363,451$ & $0.97 \%$ & & & \\
\hline & & 0.07 & Percentage & 3 & $104,866,556,980$ & & & & 0.21 & \\
\hline & \multicolumn{7}{|c|}{ Total } & $\begin{array}{l}4-5 \\
3-3.99 \\
1-2.99 \\
\end{array}$ & 3.40 & $\begin{array}{c}\text { Meets } \\
\text { Expectations }\end{array}$ \\
\hline \multirow{9}{*}{ Customer } & \multirow[t]{9}{*}{$\begin{array}{l}\text { Increase in } \\
\text { Customers } \\
\text { Service }\end{array}$} & 0.175 & $\begin{array}{l}\text { Respond to } \\
\text { customers who } \\
\text { come to the } \\
\text { counter }\end{array}$ & 5 & 35 & 35 & $100 \%$ & & 0.875 & \\
\hline & & 0.15 & $\begin{array}{l}\text { Show an } \\
\text { attitude of } \\
\text { helping } \\
\text { customers }\end{array}$ & 5 & 30 & 30 & $100 \%$ & & 0.75 & \\
\hline & & 0.05 & $\begin{array}{l}\text { Take goods } 2 \\
\text { minutes in the } \\
\text { stock room }\end{array}$ & 5 & 10 & 10 & $100 \%$ & & 0.25 & \\
\hline & & 0.075 & $\begin{array}{l}\text { Help the } \\
\text { counter } \\
\text { the empty one }\end{array}$ & 5 & 15 & 15 & $100 \%$ & & 0.375 & \\
\hline & & 0.05 & $\begin{array}{l}\text { Smile and Say } \\
\text { thanks for who } \\
\text { bought or not } \\
\text { buy }\end{array}$ & 5 & 10 & 10 & $100 \%$ & & 0.25 & \\
\hline & & 0.5 & $\begin{array}{l}\text { Grooming } \\
\text { according to } \\
\text { SOP }\end{array}$ & 5 & 100 & 100 & $100 \%$ & & 2.5 & \\
\hline & & & & \multirow{3}{*}{\multicolumn{2}{|c|}{ Total }} & & & $4-5$ & & Superior Result \\
\hline & & & & & & & & $3-3.99$ & 44.7 & \\
\hline & & & & & & & & $1-2.99$ & & \\
\hline \multirow{5}{*}{$\begin{array}{l}\text { Internal } \\
\text { Business }\end{array}$} & \multirow{5}{*}{$\begin{array}{l}\text { Increasere } \\
\text { Ources } \\
\text { rhuman }\end{array}$} & 0.5 & $\begin{array}{l}\text { Leadership } \\
\text { (Leadership) }\end{array}$ & 4 & 50 & 35 & $85 \%$ & & 2 & \\
\hline & & 0.5 & $\begin{array}{l}\text { Layout and } \\
\text { convenience } \\
\text { (Visual } \\
\text { Ambiance) }\end{array}$ & 4 & 50 & 35 & $85 \%$ & & 2 & \\
\hline & & & & \multirow{3}{*}{\multicolumn{2}{|c|}{ Total }} & & & $4-5$ & & Superior Result \\
\hline & & & & & & & & $3-3.99$ & 4 & \\
\hline & & & & & & & & $1-2.99$ & & \\
\hline \multirow{3}{*}{$\begin{array}{l}\text { Learning and } \\
\text { Growth }\end{array}$} & \multirow[t]{3}{*}{$\begin{array}{l}\text { Improve } \\
\text { Employee } \\
\text { Communicat } \\
\text { ion }\end{array}$} & 0.5 & $\begin{array}{lr}\text { Number and } \\
\text { type } \\
\text { employee } \\
\text { training }\end{array}$ & 3 & 50 & 45 & $90 \%$ & & 1.5 & \\
\hline & & 0.5 & $\begin{array}{l}\text { Compliance } \\
\text { percentage } \\
\text { and employee } \\
\text { requests }\end{array}$ & 3 & 50 & 45 & $90 \%$ & & 1.5 & \\
\hline & & & & \multicolumn{2}{|c|}{ Total } & & & $4-5$ & 3 & $\begin{array}{c}\text { Meets } \\
\text { Expectations }\end{array}$ \\
\hline
\end{tabular}

1. Financial Perspective

From the results obtained, the Financial Perspective Employee Performance Measurement for F1 (Percentage of Sales Income) gets a weighted score of 2.19. Meanwhile, F2 (Percentage of EBIT Operating 
Profit) gets a weighted score of 1.00. Meanwhile, F3 (Percentage of Lost Figures during the Sales Process) gets a Weighted Score of 0.21 .

Financial Perspective gets a score of 3.40 or Meets Expectation so it gets a yellow color. The score is obtained from the Percentage of Annual Sales with a target achievement of $100.12 \%$ with a weighted score of 2.19. While the percentage of operating profit reached $178.17 \%$ with a weighted score of $1.00 \%$ and the percentage of loss or shrinkage with the achievement of $0.97 \%$ with a weighted score of 0.21 .

2. Customer Perspective

From the results obtained, the Customer and Consumer Perspective Employee Performance Measurement for PK1 (Responding to customers who come to the counter) gets a weighted score of 0.875 . PK2 (Shows an attitude of helping customers) gets a score of 0.75. PK3 (Take goods for a maximum of 2 minutes in the stock room) gets a score of 0.25 . PK4 (Helping an empty counter) scores 0.375 . PK5 Smile and say thank you to people who bought or didn't get a score of 0.25 . While PK6 (Grooming according to SOP) gets a score of 2.5 .

Customer Perspective gets green with a score of 44.7 or Superior Result. This score is obtained from responding to customers who come to the counter with $100 \%$ of a weighted score of 0.875 . Showing an attitude of helping customers get $100 \%$ achievement with a weighted score of 0.75 . Taking the item 2 minutes in the stock room gets a $100 \%$ score with a weighted score of 0.25 . Helping the empty counter get an achievement of $100 \%$ with a weighted score of 0.375 . Smile and say thank you to those who buy or don't buy, get a score of $100 \%$ with a weight of 0.25 . and Grooming according to the standards get $100 \%$ achievement with a weight of 2.5 .

3. Internal Business Perspective

From the results obtained, the Internal Business Process Perspective Employee Performance Measurement for PBI1 (Leadership / Leadership) gets a weighted score of 0.5 while PBI2 (Layout and Convenience) gets a weighted score of 0.5 .

Internal Business Perspective gets a green color with a score of 4 or Superior Result. This score is obtained from leadership (leadership) as well as layout and comfort (visual and ambiance), both of which get the same score, namely $85 \%$ with a weighting score of 2 .

4. Learning and Growth Perspective

From the results obtained, the Employee Performance Measurement Growth and Learning Perspectives for PP1 (Number and type of employee training) received a weighted score of 0.5, while PP2 (Percentage of fulfillment and employee demand) received a weighted score of 0.5

The learning and growth perspective gets a score of 3 or yellow, it is obtained from the number and type of employee training and the percentage of employee fulfillment and interest with the same achievement results, namely $90 \%$ with each score of 1.5 .

\section{CONCLUSION AND RECOMMENDATION}

Based on the results of research and discussion, as well as observations made by researchers at PT Matahari Department Store Ciputra Cibubur, the conclusions that can be put forward are as follows:

1. Measuring employee performance using a financial perspective is at the level that meets expectations.

2. Measuring employee performance using the customer perspective is at the superior result.

3. Measuring employee performance using an internal business perspective is at a superior result level

4. Measuring employee performance using a learning perspective and the growth is at the level that meets expectations

The performance measurement used is still using the Key Performance Indicator, the measurement indicator is still not optimal. Performance appraisal is still subjective, HRD development has not been maximal because it has not carried out training and coaching.

\section{REFERENCES}

Ariningsih, D. (2014). Human Resource Performance Measurement Using Analysis Hierarchy Process Human Resource Method (Case Study at the Central Library of the Muhammadiyah University of Surakarta). Industrial Engineering Scientific Journal, 1-15.

Becker, Brian E. et.al. 2019. The HR Scorecard: Linking People, Strategy and Performance, Translated Dian Rahadyanto Basuki, Jakarta: Erlangga. 
Baharuddin. (2017). Educational Psychology. Yogyakarta: Ar-Ruzz Media.

Basrowi. (2016). Entrepreneurship for Higher Education. Bogor: Ghali Indonesia.

Hans, B. 2014. Human Resource = Company Life. Article.http://www.kompasiana.com/hans baihaqi / 54f91d67a3331b77f8b46 5a / Human- resource- company life.

Industry, JT (2017). Human Resource Performance Measurement With Human Resource Scorecard At Pt. Trio Jaya Steel Carina Lorisa 1 and Carla Olyvia Doaly 22.7 (3).

Masruroh, N. 2012. Performance Measurement Using Human Resource Scorecard to Improve Performance at PT. King Wali Tanjungsari. Tekmapro Journal of Industrial Engineering and Management. pp. 93105.

RA Tammie, BN (2018). Analysis of the Entrepreneurial Environment: A Case Study of Class XII Vocational School Students. Journal of Education and Business, 71-80.

Rivai, Veithzal, and Deddy Mulyadi, 2012, Leadership and Organizational Behavior, Third Edition, Ninth Edition, Publisher: PT. Raja Grafindo Persada, Bandung

Rusindiyanto. 2009. "Human Resources Performance Analysis using the Human Resource Scorecard (HRSC) method (Case study at PT. Arto Internasional Sidoarjo)", Journal of Engineering Science Research, Vol. 9. No.

Sahaya, AR, \& Wahyuni, HC (2017). Measuring Employee Performance Using the Human Resources Scorecard and AHP Method (Case Study: PT. Bella Citra Mandiri Sidoarjo). 4 (2), 137-145.

Sifa Farida, AN (2016). The Influence of Entrepreneurship Education, Family Environment, and Self Efficacy on Entrepreneurial Interest in Class XI Students of the Accounting Skills Program of SMK Negeri 9 Semarang. Economic Education Analysis Journal, 273-289.

Sugiyono. 2012. Qualitative and Quantitative Research Methods R \& D. Bandung: Alfabeta

Susanto, SC (2017). The Influence of Family Environment, Entrepreneurship Education, and Self-Efficacy on Students' Entrepreneurial Interest. Journal of Management and Business Star-Up, 277-286

Thomas L. Saaty, 2008. Decision making with the analytic hierarchy process, International Journal Services Sciences, Vol 1 No 1, 83- 98

Welan, J., Rondonuwu, CN, Management, J., Sam, U., \& Manado, R. (2018). Measuring Employee Performance Using The Human Resource Scorecard Method At Pt. Hasjrat Abadi Tendean Manado Employee Performance Measurement With Using Human Resource Scorecard Method At Pt. Hasjrat Abadi Tendean Manado. 6 (4), 4123-4132.

Wibowo. 2017. Performance Management. Jakarta: PT Raja Press.

Zaini, H., \& Suryadi, A. (2020). Analysis of Company Performance Using the Human Resource Scorecard (Hrsc) Method at Cv. Xyz. Juminten, 1 (1), 151-161. https://doi.org/10.33005/juminten.v1i1.70 